\title{
$\mathrm{CTAB} / \mathrm{NaSal}$ 水溶液の平行平板間せん断流れにおけるクリープ試験・ 流動複屈折測定および可視化実験*
}

\author{
山下 敦史 ${ }^{* 1}$, 森 綱規 $* 2$, 沢 和洋 $* 2$, 山本 岡宏 $* 1$
}

\section{Creep Tests, Flow Birefringence Measurements, and Flow Visualization of Aqueous Solutions of CTAB and NaSal in Shear Flow between Parallel Plates}

\author{
Atsushi YAMASHITA, Kouki MORI, Kazuhiro SAWA and Takehiro YAMAMOTO*1 \\ ${ }^{* 1}$ Department of Mechanical Engineering, Graduate School of Engineering, Osaka University \\ 2-1, Yamadaoka, Suita-shi, Osaka, 565-0871, Japan
}

\begin{abstract}
Creep tests, flow birefringence measurements, and flow visualization experiments in shear flows between parallel plates were carried out for aqueous solutions of cetyltrimethylammonium bromide (CTAB) and sodium salicylate (NaSal) with excess of NaSal. The mol concentration of CTAB was fixed to $0.030 \mathrm{~mol} / \mathrm{l}$ and the concentration ratio of NaSal to CTAB was varied. The creep tests indicate that it requires long time to develop micellar network structures for low to moderate concentrations at low shear stresses. Under conditions of shear rate at which the shear-thickening property in viscosity is observed in a flow curve, periodical changes in flow birefringence and shear stress occur and these frequencies are almost the same as that of the emergency of white turbidity observed in the flow visualization. These results indicate that relatively large structures of micellar network are induced by the shear flow and repeatedly appear and disappear.
\end{abstract}

Key Words : Surfactant Solutions, Creep Test, Flow Birefringence, Turbidity, Wormlike Micelles, CTAB/NaSal, Shear Flow

\section{1. 緒言}

カチオン系界面活性斉水溶液に塩を添加した系では，ひも状ミセルが形成され，さらに過剩な塩を添加すると， ミセルのネットワーク構造が形成される . 具化トリメチルアンモニウムブロミド (cetyltrimethylammonium bromide, $\mathrm{CTAB}$ ) とサリチル酸ナトリウム (sodium salicylate, NaSal) の水溶液はミセルネットワークを形成する試料とし てよく知られている. Shikata ら ${ }^{(1) \sim(4)}$ は CTAB/NaSal 系のレオロジー特性を調べ, CTAB/NaSal 水溶液か顕著な粘 弾性を示し，光れがミセルのネットワークに起因することを示した．この系は, 単一緩和モードのマクスウェル モデルで記述される緩和時間や平坦部を有する流動曲線のように，特徵的なレオロジー特性を有する．この系の レオロジー特性は, これまでに多くの研究者たちによって精力的に研究されてきた ${ }^{(1) \sim(8)}$.

さらに, CTAB/NaSal 系の流動挙動に関する研究では, シアバンディングや白濁現象といった興味深い現象か報 告されている . シアバンディングは現在 , 熱心に研究されている研究分野である (例えば , 最近のレビュー ${ }^{(9)}$ (10) および关の中の引用文献参照) .この現象は, ひも状ミセル溶液, 液晶, 濃厚コロイド溶液, エマルションなどで 見られる.シアバンディングが発生すると，せん断流れ中で等方相と配向相が共存し，バンド状の構造を形成す る . シアバンディングの発生は, 流動曲線におけるせん断応力のせん断速度への非単調依存性に起因していると 考えられている.CTAB/NaSal 溶液については, クエット流れ中のシアバンディングの研究として, 流動複屈折測 定 ${ }^{(11)(12)}$, 小角光散乱 (SALS) 測定 ${ }^{(13)}$, 流速測定 ${ }^{(12)(14)(15)}{ }^{(15}$ 行われてきた . また, 粘度の shear-thickening 性か現 れるせん断速度域で白濁現象が見られる ${ }^{(16)}$. 樣々な研究において，ひも状ミセル溶液におけるシアバンディング と白濁現象の関連性か涽摘されている ${ }^{(17) \sim(19)}$.

\footnotetext{
* 原稿受付 2011 年 2 月 3 日, Journal of Fluid Science and Technology,Vol.4,No.3(2009),pp.699-710 (原稿受付 2009 年 7 月 6 日)

*1 正員, 大阪大学大学院工学研究科機械工学専攻 (广 565-0871 大阪府吹田市山田丘 2-1)

$* 2$ 大阪大学大学院工学研究科機械工学専攻 (广 565-0871 大阪府吹田市山田丘 2-1)

Email: take@mech.eng.osaka-u.ac.jp
} 


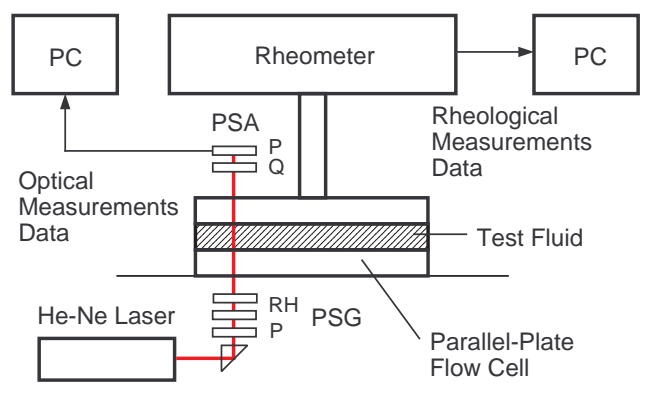

(a)

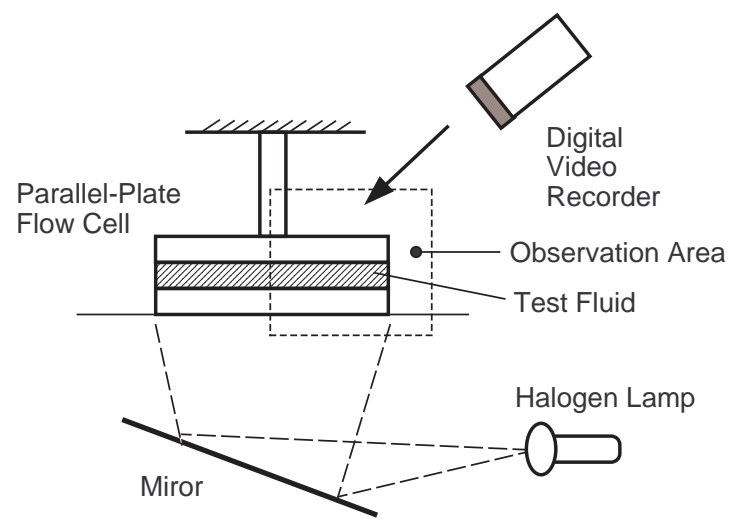

(b)

Fig. 1 Schematic diagram of experimental setup for (a) flow birefringence measurements and for (b) the flow visualization: The birefringence measuring system is composed of a polarization state generator (PSG) consist of a polarizer $(\mathrm{P})$ and a rotating half-wave plate $(\mathrm{RH})$ and a polarization state analyzer (PSA) consists of a polarizer $(\mathrm{P})$ and a quarter-wave plate $(\mathrm{Q})$.

$\mathrm{CTAB} / \mathrm{NaSal}$ 溶液の可視化実験では，種々の流れにおいて白濁現象が報告されている．例えば，クエット流れ

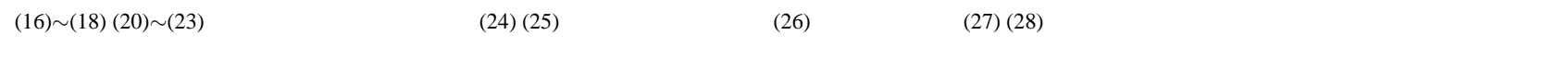
起される白濁現象は， $\mathrm{CPyCl} / \mathrm{NaSal}$ 系 ${ }^{(19)(29)(30)}$ や $\mathrm{TAT} / \mathrm{NaSal}$ 系 ${ }^{(31)}$ などの他の界面活性斉溶液でも観察されている . 白濁現象は，せん断誘起構造 (shear induced structure, SIS) の発生と考えられている.さらに, 白濁現象の発生は ミセルネットワークのようなミクロ構造の変化の現れであると考えられる. Kadoma と Egmond ${ }^{(32)}$ は, SIS の研究 のために，CTAB/NaSal 系の単純せん断流れに対して SALS 実験を行い，流動方向に配向する強く伸長されたひ も状構造か誘起されることを見出した。 Wheeler ら ${ }^{(29)}$ は, $\mathrm{CPyCl} / \mathrm{NaSal}$ 溶液の平行平板間流れにおいて, 環状の 白濁構造と流動複屈折の振動を観測し，流動複屈折のピークか環状白濁領域に対応することを見出した．さらに， SALS 測定によって，流動方向に配向した伸長構造が現れることを示した．

平行平板間のせん断流れ中のひも状ミセル溶液の流動挙動は, 十分には研究されておらず, 流れによって誘起さ れるミセルネットワーク構造の変化と白濁現象の発生との関係は解明されていない.また, 白濁現象のせん断速度 依存性についても明らかにはされていない，本研究では，白濁現象が発生する条件下の平行平板間流れに着目し， 白濁現象とミセルネットワークの流動誘起構造との関係を調べるために, クリーブ試験, 流動複屈折測定, 可視化 実験を行った .ここでは，種々の濃度で NaSal を過剩に添加した CTAB/NaSal 水溶液を試料流体として使用した。

\section{2. 実 験 方 法}

$2 \cdot 1$ 実験装置および方法

試料流体のレオロジー特性は, 回転型レオメーター（Anton Paar 製 Physica MCR 300）を用いて測定された . 本 研究では, 半径 $25 \mathrm{~mm}$ の一対の円板からなる平行平板型のセルを使用した . 平行平板型セルの場合, 円板中心か ら距離 $r$ の位置における局所せん断速度 $\dot{\gamma}$ は， $\dot{\gamma}(r)=(\Omega / h) r$ で表される .ここで $\Omega$ は回転円板の角速度， $h$ は平 
Table 1 Concentration ratio $S=C_{S} / C_{D}$ and the relaxation time $\lambda$ of test fluids. $C_{S}$ and $C_{D}$ are the mol concentrations of CTAB and NaSal, respectively.

\begin{tabular}{c||r|r|r|r|r|r|r}
\hline \multicolumn{1}{c||}{$C_{D}(\mathrm{~mol} / \mathrm{l})$} & \multicolumn{8}{c}{0.030} \\
\hline$C_{S}(\mathrm{~mol} / \mathrm{l})$ & 0.039 & 0.045 & 0.060 & 0.090 & 0.12 & 0.15 & 0.23 \\
\hline$S=C_{S} / C_{D}$ & 1.3 & 1.5 & 2.0 & 3.0 & 4.0 & 5.0 & 7.7 \\
\hline$\lambda(\mathrm{s})$ & 0.946 & 0.723 & 0.580 & 1.11 & 1.29 & 1.39 & 0.973 \\
\hline
\end{tabular}

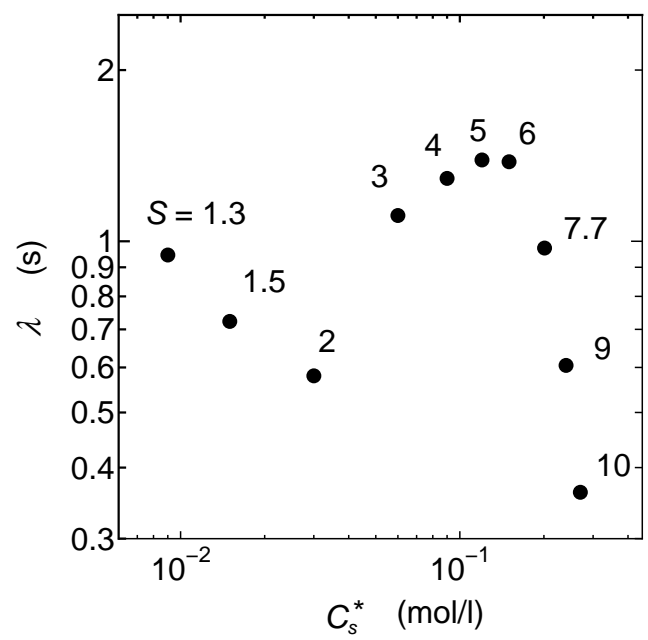

Fig. 2 Relation between relaxation time $\lambda$ and the concentration of free salicylate ion $C_{S}^{*}$ at $23{ }^{\circ} \mathrm{C}$.

板間距離で, $h$ を $0.5 \mathrm{~mm}$ に固定した . また , せん断応力とせん断速度の関係は次式で与えられる ${ }^{(33)(34)}$.

$$
\tau_{R}=\frac{T}{2 \pi R^{2}}\left(3+\frac{\dot{\gamma}_{R}}{T} \frac{d \ln T}{d \ln \dot{\gamma}_{R}}\right),
$$

ここで $\tau_{R}$ と $\dot{\gamma}_{R}$ は，乥れ光れ円板外周 $(r=R)$ におけるせん断応力とせん断速度， $T$ は円板にはたらくトルクで ある．本実験で使用したレオメーターは，応力制御とひずみ速度制御の両方式で測定が可能である．乥こで，ク リーブ試験では，一定のせん断応力を試料流体に加え，ひずみ速度の応答を計測した．

流動複屈折測定および可視化実験では, 標準のステンレス製円板セルの代わりに, 光学ガラス製の透明な平行 円板セルを使用した . ガラス円板の寸法は標準円板セルのものと同じである . 図 1 に実験装置の概略図を示す . 本実験では，回転式偏向変調型複屈折測定装置 ${ }^{(35)}{ }^{(36)}$ を使用した . 波長 $632.8 \mathrm{~nm}$ の He-Neレーザー光 (NEC 製 GLG5360) を光源として用いた . 流動複屈折測定と同時にせん断応力 $\tau_{R}$ も測定した . 可視化実験では, ハロゲン ランプ (波長スペクトル 250〜2500 nm) を光源として使用し，デジタルビデオカメラ (SONY 製 DCV-VX1000)

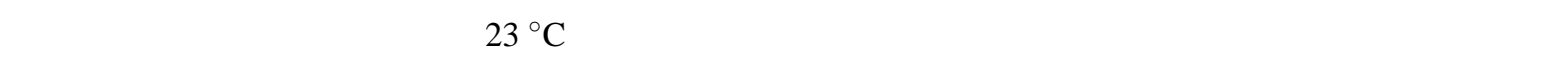

\section{$2 \cdot 2$ 試料流体}

試料流体は CTAB と NaSal の水溶液で, 溶媒として蒸留水を用いた . 濃度比 $S$ を, CTAB と NaSal のモル濃度 $C_{D}$ と $C_{S}$ を用いて $S=C_{S} / C_{D}$ で定義し，本論文では濃度比で試料流体を識別する．本実験では， $C_{D}$ を $0.030 \mathrm{~mol} / \mathrm{l}$ に固定し， $C_{S}$ を変化させた。試料流体の濃度比を表 1 に示す。

単一緩和時間マクスウェルモデルの緩和時間 $\lambda$ を, 円錐円板型レオメーターを用いた動的粘弾性測定の結果から 評価した ${ }^{(37)} . \lambda$ と溶液中の自由なサリチル酸ナトリウムイオンの濃度 $C_{S}^{*}$ との関係を图 2 に示す. Shikata ら ${ }^{(1)(2)}$ は, NMR 測定の結果から $C_{S}^{*}$ を見積もり， $C_{S}^{*}=C_{S}-C_{D}$ という関係を見出した . さらに , 彼らは $C_{S}>C_{D}$ のとき の CTAB/NaSal 系の緩和時間は $C_{S}^{*}$ のみに依存し，単一緩和時間のマクスウェルモデルで表されることを示した . 図 2 に示すように，緩和時間は $C_{S}^{*}$ に依存し，Sが 2.0 付近で極小值を，Sが 5.0 付近で極大值をとる.緩和時間は ネットワーク中の絡み合いの状態を反映している. Shikata ら ${ }^{(2)}$ は,$C_{S}>C_{D}$ における CTAB/NaSal 水溶液の緩和 時間は，ミセル同士が絡み合い点で絡み合いの生成や切断をともなって互いにすり抜ける過程に関連すると説明 


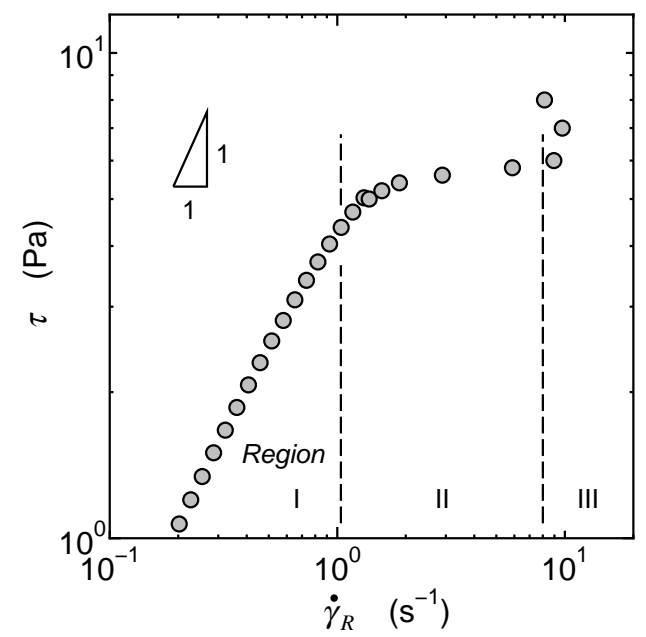

Fig. 3 Classification of regions in flow curve for the CTAB/NaSal solutions of $S=2.0$ measured with a parallel-plate rheometer at $23{ }^{\circ} \mathrm{C}$.

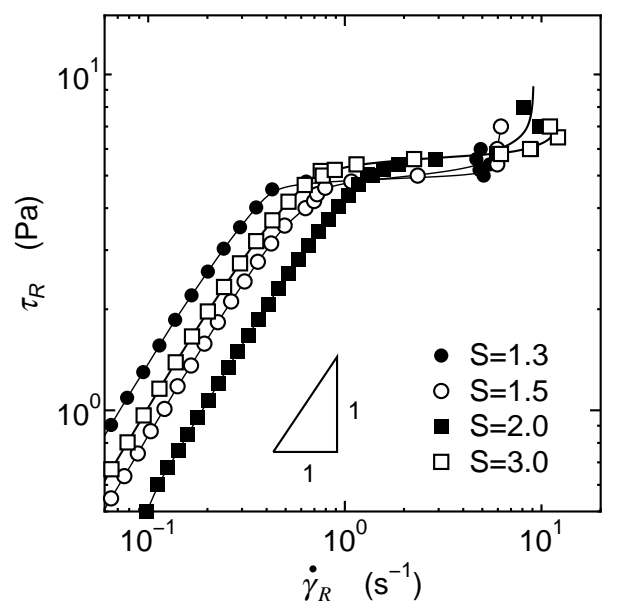

(a)

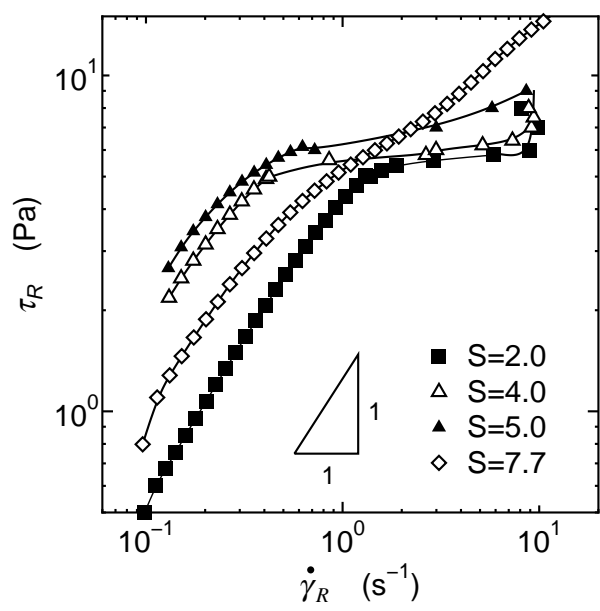

(b)

Fig. 4 Dependence of flow curve for the $\mathrm{CTAB} / \mathrm{NaSal}$ solutions on the concentration ratio $S$ at $23{ }^{\circ} \mathrm{C}$ : (a) $S=1.3-3.0$, (b) $S=2.0$ and 4.0-7.7.

した .この理論によれば, $\lambda$ の大きい溶液ほど，ミセルネットワークはより多くの絡み合い点を有していること になる．各試料流体の緩和時間を表 1 に示す.

$\mathrm{CTAB} / \mathrm{NaSal}$ 系は流動曲線において非単調挙動を示す. 平行平板型レオメーターで測定した試料流体の流動曲線 を図 3 に示す．一般的には，流動曲線のようなレオロジー特性を測定するためには，円錐円板型レオメーターを 使用するが, ここでは, クリープ試験，流動複屈折測定，可視化実験で使用したものと同じ平行平板型レオメー ターで測定した流動曲線を示す .これらのデータは, 円錐円板型レオメーターで測定したもの ${ }^{(37)}$ と定性的に同じ 傾向を示すことを確認している．また，ここで示した流動曲線は，クリープ試験において定常值として得られた データをプロットしたものである．

図 3 に示すように， $S=2.0$ の溶液の流動特性は 3 つの領域に分類できる . 領域 I はせん断応力がせん断速度に 線形に依存するニュートン領域である．領域 II では，流動曲線は shear-thinning 特性を示す．光して，領域 III で は shear-thickening 特性が見られる. 図 4 に，S=1.3 1.5, 2.0, 3.0, 4.0, 5.0, 7.7 の場合の流動曲線を示す .これら のデータも平行平板型レオメーターで測定したものである. $S=2.0$ の場合と同樣に, 各試料流体の流動曲線は基 本的に 3 つの領域，すなわち，ニュートン領域， shear-thinning 領域， shear-thickening 領域に分類できる.ただし， 図 $4 \mathrm{~b}$ に示すように , 大きな $S(S=4.0,5.0,7.7)$ の溶液では, 低せん断速度域で shear-thinning 性が見られ， $S=7.7$ 


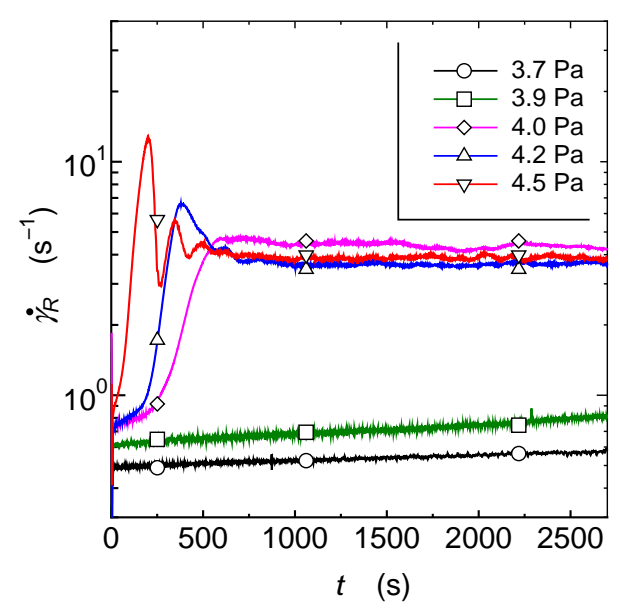

(a)

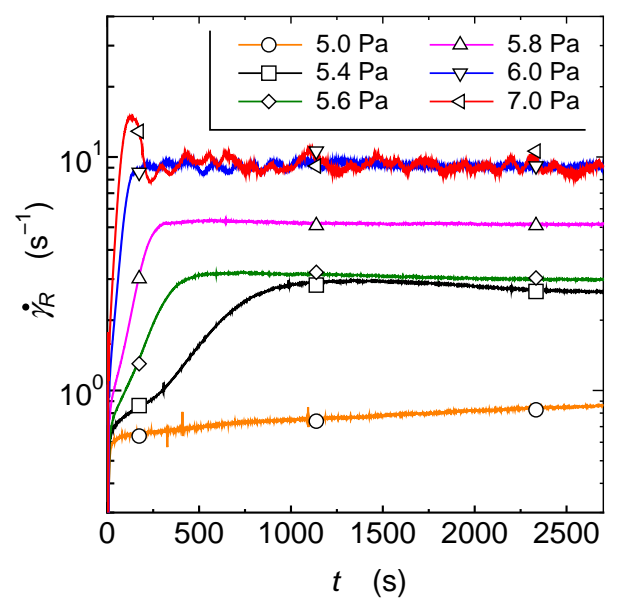

(c)

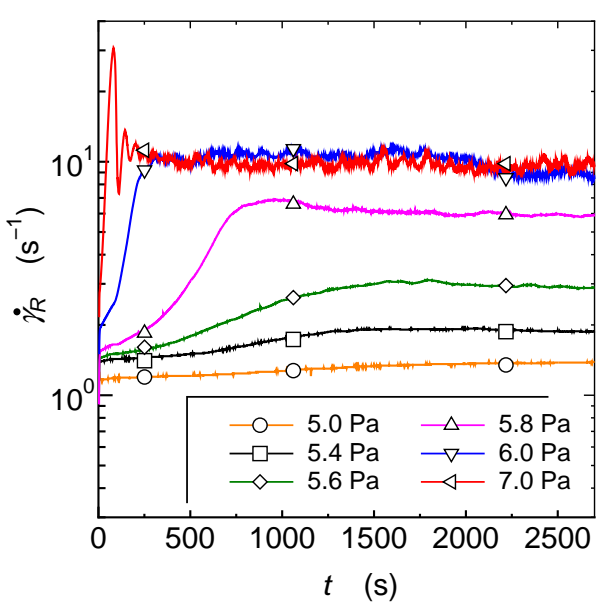

(b)

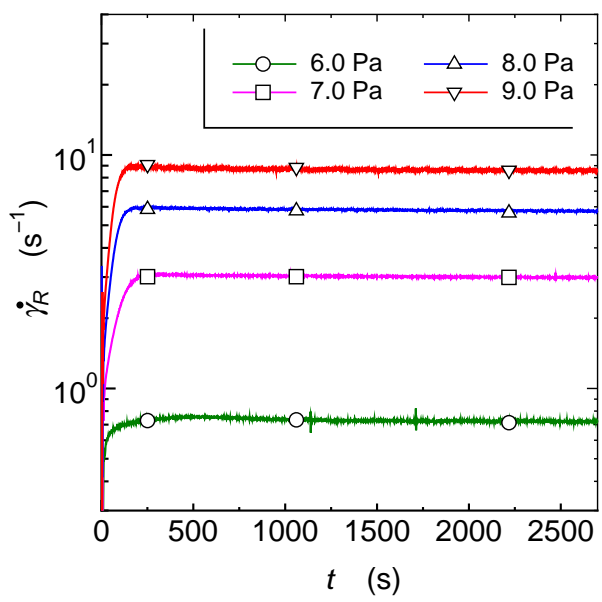

(d)

Fig. 5 Results of creep tests, shear rate $\dot{\gamma}_{R}$ versus time $t$, for the solutions of $S=$ (a) 1.3, (b) 2.0, (c) 4.0, and (d) 5.0 at $23^{\circ} \mathrm{C}$. Marks are plotted for identification.

では高せん断速度における shear-thickening 性が見られない . せん断応力 $\tau_{R}$ は濃度比 $S$ に非単調的に依存し，緩 和時間 $\lambda$ に関連がある . 各流体の流動曲線は領域 I, II で $\lambda$ の順に並んでいる .

\section{3. 結 果と考 察}

\section{$3 \cdot 1$ クリープ試験}

平行平板型レオメーターを用いて CTAB/NaSal 溶液のクリープ試験を行い , 低中濃度比の場合には , ミセルネッ トワーク構造の変化に比較的長い時間が必要となることが分かった . また，クリーブ試験の定常值を試料流体の 流動曲線を得るために用いた . 応力制御下で, 所定のせん断応力 $\tau_{R}$ を平板間の溶液に加え, せん断速度 $\dot{\gamma}_{R}$ の応 答を記録し，負荷応力を変えて試験を行った。

図 5 にクリーフ試験の結果を示す. $S$ が小さいときの結果（図 5a〜 5c) では, 比較的せん断応力が小さいと, せ ん断速度は非常にゆっくりと変化している.すなわち，ミセルネットワーク構造が成長するために長い導入時間 が必要となる，一方，ある臨界せん断応力以上では，せん断速度は急激に上昇し，才ーバーシュート現象が発生 する.図 5a に見られるように, 臨界せん断応力以上では, せん断速度 $\dot{\gamma}_{R}$ の上昇は, せん断応力が大きいほど速 くなり， $\dot{\gamma}_{R}$ はほぼ同じ值に近づいていく.すなわち, 定常状態におけるせん断速度は負荷せん断応力に依存しな い.これらの結果は，ミセルネットワークの構造変化が，ある臨界せん断応力以上で起きることを示唆している． $S=2.0,4.0$ に対する結果においても，同樣の傾向が見られた . これらの $S$ が小さ流体に対して，臨界せん断応 


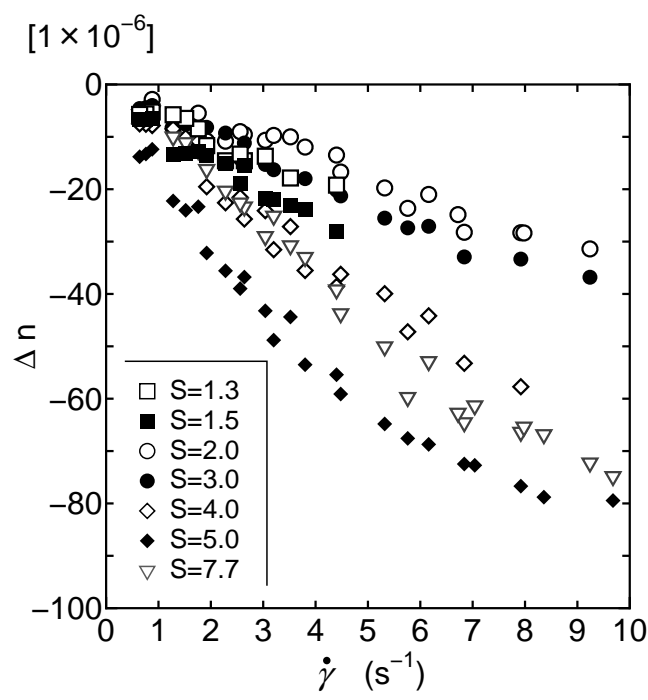

Fig. 6 Dependence of flow birefringence $\Delta n$ on shear rate $\dot{\gamma}$ in the region II for the solutions of $S=1.3,1.5$, 2.0, 3.0, 4.0, 5.0, and 7.7 at $23^{\circ} \mathrm{C}$.

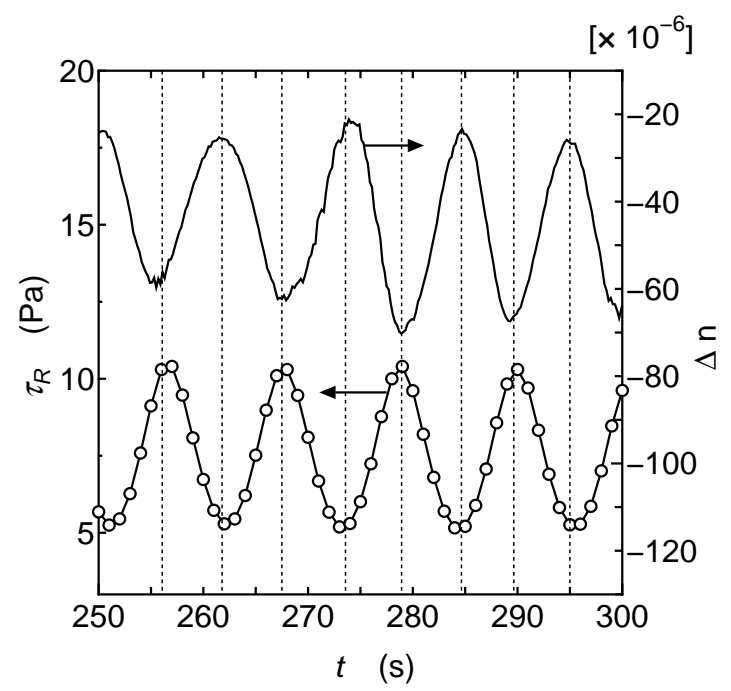

Fig. 7 Time responses of flow birefringence $\Delta n$ and shear stress $\tau_{R}$ for the solution of $S=2.0$ at $\dot{\gamma}=9.5 \mathrm{~s}^{-1}$ and $23{ }^{\circ} \mathrm{C}$.

カは 4.8 Pa から 5.4 Paの範囲の近い值をとつた .

$S$ が大きい場合, $\dot{\gamma}_{R}$ の過渡応答は $S$ の小さい場合と異なっている . 図 $5 \mathrm{~d}$ は，図 2 の $\lambda-C_{s}^{*}$ 曲線が極大値をとる $S$ $=5.0$ の場合の結果を示したものである. せん断速度は各せん断応力において急速に上昇し，定常值に近づく. 光 して, 弚の定常値はせん断応力の増加とともに大きくなっている. 本論文では結果を示していないが, $S=7.7$ の場 合にも同樣の結果を示し，応力を加えた直後の応答は $S=5.0$ のときよりも速かった . $S=4.0$ と $S=5.0$ の結果の間 には顕著な違いが見られ，ミセルネットワーク構造がこれらの $S$ の值の間で, 劇的に変化していると考えられる

\section{$3 \cdot 2$ 流動複屈折測定}

次に流動複屈折測定の結果を示す . 測定は, せん断速度制御下で, 種々のせん断速度に対して行った . 一定せん 断速度 $\dot{\gamma}_{R}$ のせん断か試料流体に加えられ，流れが定常状態になった後に流動複屈折が測定された . 測定位置は, $r$ $=22,19,16 \mathrm{~mm}$ である . 同じせん断速度では, 各測定点における測定結果に顕著な差異は認められないため, 各 点の測定結果を局所せん断速度 $\dot{\gamma}$ に対してプロットする.

图 6 は，領域 II における流動複屈折 $\Delta n$ のせん断速度 $\dot{\gamma} へ$ 依存性を，種々の $S$ の值に対して示したものである . 流動複屈折の絶対值 $|\Delta n|$ は，せん断速度の上昇とともに増大する . 粘度がこの領域で shear-thinning 性を示すこと 


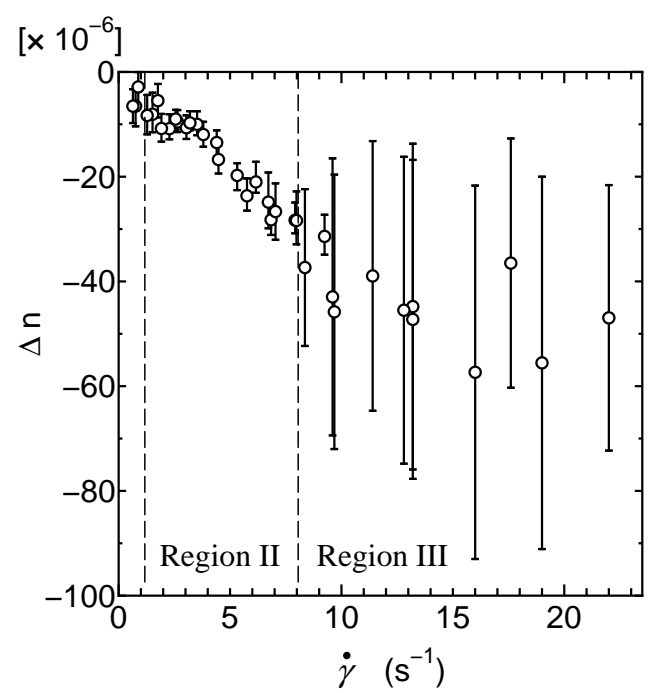

Fig. 8 Dependence of flow birefringence $\Delta n$ on shear rate $\dot{\gamma}$ in the regions II and III for the solution of $S=2.0$ at $23{ }^{\circ} \mathrm{C}$. Error bars indicate minimum and maximum values.

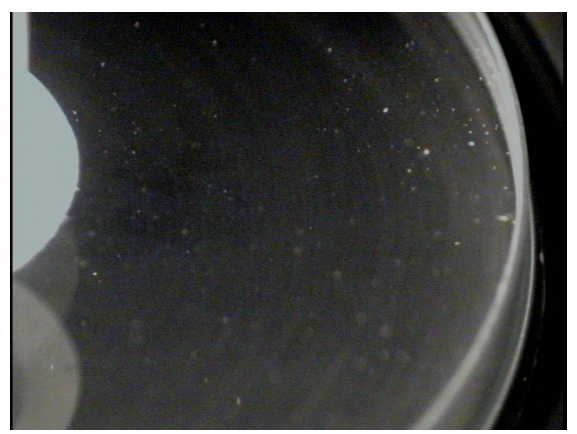

Fig. 9 Snapshot of flow between parallel plates for the solution of $S=2.0$ at $\dot{\gamma}_{R}=6.6 \mathrm{~s}^{-1}$ and $23{ }^{\circ} \mathrm{C}$.

を考慮すると, ミセルネットワーク構造の流れ方向への配向に起因する異方性が， $\Delta n$ の絶対値の増大を引き起こ していると考えられる.さらに，| $|\Delta n|$ が緩和時間 $\lambda$ にも依存していることは興味深い . すなわち , ミセルネット ワーク構造がより多くの絡み合い点を有しているほど，より配向度の高い構造がせん断流れ下で形成されている．

図 7 に $S=2.0$ の流体の $\dot{\gamma}=9.5 \mathrm{~s}^{-1}$ (領域 III) における $\Delta n$ と $\tau_{R}$ の時間応答を示す. データは $r=22 \mathrm{~mm}$ の点 で測定されたものである．流動複屈折とせん断応力は，ほぼ同じ周期 $12 \mathrm{~s}$ で周期的に時間変化し， $\Delta n$ の絶対值が 大きいときにせん断応も大きくなる . 領域 III は shear-thickening 領域に属し，この領域で見かけの粘度の上昇が 起こることから，ここでは, 領域 II で形成されている構造よりも大きな構造が流れによって誘起され, 弚れらが 周期的に生成と消滅を繰り返していると考えられる.さらに, 谷の周期は緩和時間に比べて非常に長く, 弚のこ とは比較的大きなあるいは複雑な構造が形成されていることを意味する．また，次節で示す可視化実験の結果は この考察を支持するものであった . 比較的大きな構造が形成されている白濁領域の半径方向の位置は, せん断応 力の変化に影響を与えている.

図 8 に，S=2.0のときの $\Delta n$ とせん断速度 $\dot{\gamma}$ との関係を示す . 図には領域 II の結果も示されている . 図中の誤差 棒は，最大および最小值を表し，白丸は平均值を示している. $\Delta n$ の絶対値は概ね領域 III て領域 II よりも大きく， その平均值は比較的大きな值で, せん断速度に対して大きくは変化しない．この結果は, 流動複屈折測定で捉え ている構造が流れ方向によく配向していることを示唆している.領域 III における流動複屈折は , 図 7 に示すよう に, 配向構造の生成と消滅の繰り返しに対応する周期的な変化を示す．したがって，誤差棒が大きくなっている． 


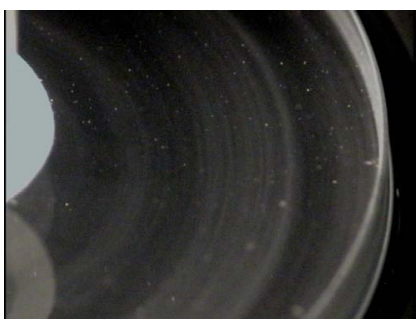

(a)

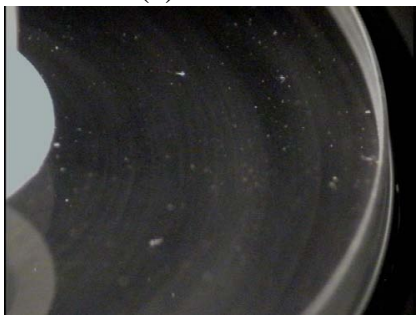

(d)

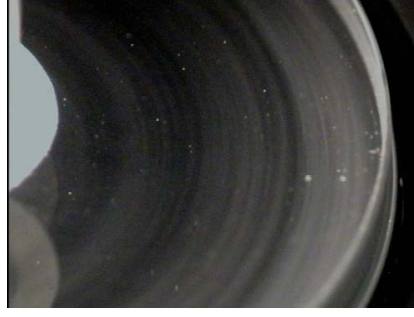

(b)

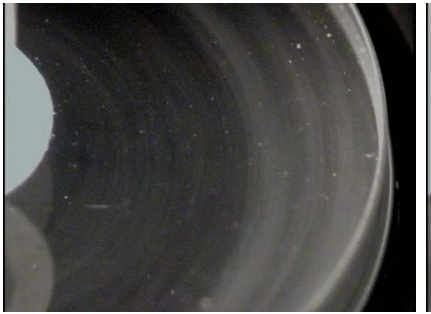

(e)

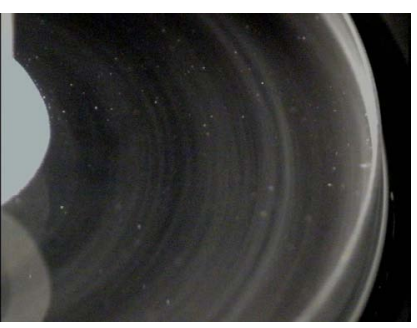

(c)

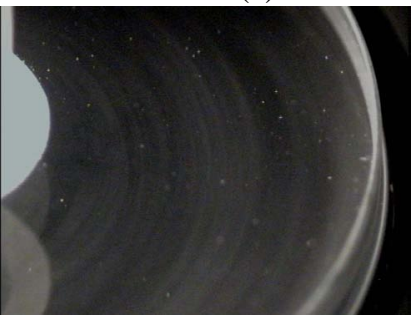

(f)

Fig. 10 Snapshots at time interval of $5.0 \mathrm{~s}$ for the solution of $S=2.0$ at $\dot{\gamma}_{R}=$ (a)-(c) $8.5 \mathrm{~s}^{-1}$ and (d)-(f) $9.5 \mathrm{~s}^{-1}$. Fluid temperature is $23{ }^{\circ} \mathrm{C}$. Time passes from (a) to (c) or from (d) to (f).

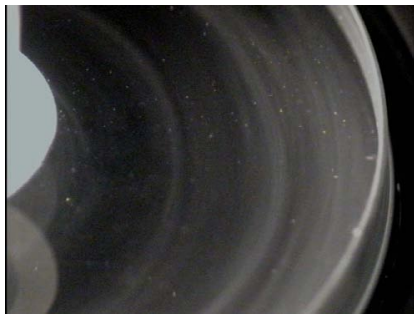

(a)

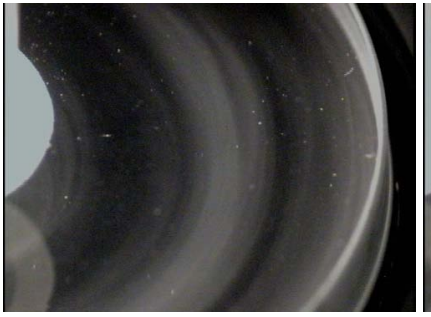

(b)

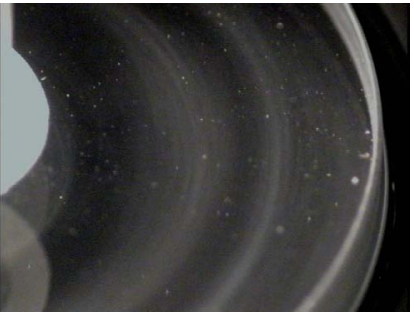

(c)

Fig. 11 Snapshots at time interval of $5.0 \mathrm{~s}$ for the solution of $S=2.0$ at $\dot{\gamma}_{R}=11.5 \mathrm{~s}^{-1}$ and $23{ }^{\circ} \mathrm{C}$. Time passes from (a) to (c).

\section{$3 \cdot 3$ 可視化実験}

次に流れの可視化実験結果を示す . 図 9 は $S=2.0$ の溶液の $\dot{\gamma}_{R}=6.6 \mathrm{~s}^{-1}$ のときの流れのスナップショットを示し ている．このせん断速度は領域 II に属する．写真左側に見える白い円の一部分は，上側円板に取り付けられた回 転軸の反射である．写真の右側に円板の縁が見られる．白濁領域が円板外周付近で同心円状に現れている．不透 明領域の移動はあまり見られず，外周付近に安定的に存在する．領域 II では，せん断速度の上昇とともに不透明 度が強くなった。

図 10 に $S=2.0$ の溶液に対する $\dot{\gamma}_{R}=8.5,9.5 \mathrm{~s}^{-1}$ における結果を示す . これらのせん断速度は領域 III に属する。 この図は $5.0 \mathrm{~s}$ の時間間隔のスナップショットである. 図 9 の場合と同樣に，白濁現象が外周付近で発生し，光の 領域は $\dot{\gamma}_{R}=6.6 \mathrm{~s}^{-1}$ の場合に比べて広くなっている. せん断速度が大きいほど，白濁領域は広くなる．領域 III で は, 非定常現象が見られた . 白濁領域は周期的に発生と消滅を繰り返し, 透明状態と不透明状態間の周期的な変化 か観察された . 図 10a, 10d では白濁領域は明瞭には観察されず，しばらくしてから白濁領域か現れ (図 10b, 10e) ， 兴の後再び消滅してセルは透明になる . 図 11 は , より高せん断速度の $\dot{\gamma}_{R}=11.5 \mathrm{~s}$ におけるスナップショットであ る.流れは不安定で, セルの一部で白濁領域の生成と消滅が不規則的に現れた。

\section{4 流動複屈折, せん断応力, 白濁現象の関係}

図 8 に示すように，領域 III で流動複屈折およびせん断応力の周期的変化が観測された $\dot{\gamma}=9.5 \mathrm{~s}^{-1}$ における各 応答の周期は約 $12 \mathrm{~s}$ でほぼ同じである. 可視化実験においても約 $12 \mathrm{~s}$ の周期で模樣の周期的変化が見られた . 白 濁領域で, 光を散乱する程度の比較的大きな構造が作られていると考えられる．さらに，白濁領域では，流動複 


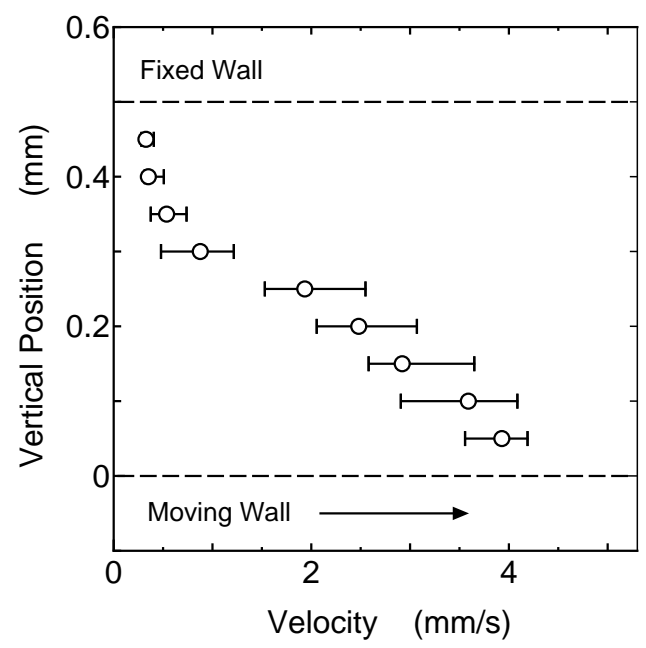

Fig. 12 Banded velocity profile for the CTAB/NaSal solution of $S=2.0$ in the flow between parallel plates at $\dot{\gamma}=8.0 \mathrm{~s}^{-1}$.

屈折の絶対値が大きく，せん断応力は増大している .これらの結果は, 比較的大きな配向構造の発生が見かけの 粘度の増大を引き起こしていることを示している . 流動複屈折の測定は, 大きな構造の一部の配向構造を捉えて いると考えられる．

領域 III における実験結果から，この領域におけるミセルネットワーク構造の変化は次のように説明できる．ミ セルネットワーク構造が疑集して，大きな散乱体を形成し，弚れがせん断流れによって流れ方向に配向する．凝 集構造は周期的に生成と消滅を繰り返し，光れが流動複屈折の振動を引き起こす．また，環状白濁領域の不規則 な移動と後述の流路厚み方向の速度分布の变動（図 12）は，領域 III で不安定流れが発生していることを示唆し ている. Kadoma と Egmond ${ }^{(32)}$ は単純せん断流れ下で, $C_{D}=0.03 \mathrm{~mol} / \mathrm{l}, S=8$ のCTAB/NaSal 溶液を用いて SALS 実験を行い，流れ方向に配向し強く伸長されたひも状構造が誘起され，配向したひも状構造と周囲流体間で，長 距離スケールの濃度変動が発生することを見出した . Wheeler ら ${ }^{(29)}$ は, 平行平板 , 円錐円板およびクエットセル を用いて, CPyCl/NaSal 系の SIS と流動不安定を研究した . 彼らは, 平行平板および円錐円板セルて環状白濁領域 を，クエットセルでバンド状の構造を観察した .さらに , 流動複屈折測定および可視化実験から , SIS が成長する と，SIS によって引き起こされた流動不安定によりSIS が破壊されることを示した .これらの結果は上述の仮説を 支持するものである .

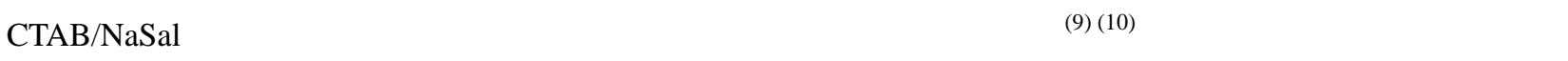
の研究グループによっても，PTV (Particle Tracking Velocimetry) による流速測定により, 平行平板間のせん断流れ で層状の速度分布 ${ }^{\left({ }^{39}\right)}$ が見出されている.我々の実験では, Cambridge shearing system (Linkam Scientific Instrument 製 CSS-450) を用いて試料流体にせん断を加え，観測密を通して光学顕微鏡で試料流体の流れを観察した . トレー サー粒子の運動を高速度 CCD カメラにより撮影し，焦点前後の顕微鏡レンズの被写界深度内にある粒子のみが鮮 明に観察されるという特性を利用して，ある位置の速度をPTVにより評価した . 図 12 に流速測定結果の一例を 示す . 各測定点の平均流速を白丸で示し, 速度変動の範囲を横棒で示した . 層状の速度分布が明瞭に見られる . こ れらのことから，流路内で鉛直方向のシアバンディングも発生し，配向相と等方相の層状領域が共存していると 考えることは妥当である．したがって，領域 III では複雑なミクロ構造が形成されていると考えられるが，ミセル ネットワーク構造変化の基本的な描像は上述のように説明できると考えられる .

\section{4. 結言}

本研究では, $\mathrm{CTAB}$ 濃度 $C_{D}$ が $0.030 \mathrm{~mol} / \mathrm{l}$ で $\mathrm{NaSal}$ 濃度が異なる数種類の $\mathrm{CTAB} / \mathrm{NaSal}$ 水溶液の平行平板間せん 断流れに対して,クリーブ試験，流動複屈折測定，可視化実験を行った .クリーブ試験では，図 2 の- $C_{S}^{*}$ 曲線で 系の緩和時間が極大值をとる $S=5.0$ 付近の濃度で, $\mathrm{CTAB} / \mathrm{NaSal}$ 系の応答の樣子が変化した . 流動複屈折測定の 
結果では，流動複屈折の絶対値がせん断速度の増加とともに大きくなり， shear-thinning 領域 (領域 II) において， せん断流れがミセルネットワークの配向を誘起することが示された . shear-thickening 領域 (領域 III) では, 流動 複屈折とせん断応力が周期的に時間変化し，この現象が可視化実験における白濁領域の周期的発生と対応するこ とが分かった .この現象は, 流動によって誘起されるミセルネットワーク構造の凝集の生成と消滅の繰り返しに よって引き起こされていると考えられる .

謝 辞

本研究の一部は, 科研費 (No.20360084) の助成を受けたものである .

文献

(1) Shikata, T., Hirata, H., Kotaka, T., "Micelle Formation of Detergent Molecules in Aqueous Media: Viscoelastic Properties of Aqueous Cetyltrimethylammonium Bromide Solutions”, Langmuir, Vol.3, No.6 (1987), pp.1081-1086.

(2) Shikata, T., Hirata, H., Kotaka, T., "Micelle Formation of Detergent Molecules in Aqueous Media. 2. Role of Free Salicylate Ions on Viscoelastic Properties of Aqueous Cetyltrimethylammonium Bromide-Sodium Salicylate Solutions”, Langmuir, Vol.4, No.2 (1988), pp.354-359.

(3) Shikata, T., Hirata, H., Takatori, E., Osaki, K., "Nonlinear Viscoelastic Behavior of Aqueous Detergent Solutions", Journal of Non-Newtonian Fluid Mechanics, Vol.28, Nos.2-3 (1988), pp.171-182.

(4) Shikata, T., Hirata, H., Kotaka, T., "Micelle Formation of Detergent Molecules in Aqueous Media. 3. Viscoelastic Properties of Aqueous Cetyltrimethylammonium Bromide-Salicylic Acid Solutions”, Langmuir, Vol.5, No.2 (1989), pp.398-405.

(5) Wheeler, E.K., Izu, P., Fuller, G.G., "Structure and Rheology of Wormlike Micelles", Rheologica Acta, Vol.35, No.2 (1996), pp.139-149.

(6) Hartmann, V., Cressely, R., "Linear and Non-Linear Rheology of a Wormlike Micellar System in Presence of Sodium Tosylate", Rheologica Acta, Vol.37, No.2 (1998), pp.115-121.

(7) Kim, W.J., Yang, S.M., "Effects of Sodium Salicylate on the Microstructure of an Aqueous Micellar Solution and Its Rheological Responses", Journal of Colloid and Interface Science, Vol.232, No.2 (2000), pp.225-234.

(8) Rothstein, J.P., “Transient Extensional Rheology of Wormlike Micelle solutions”, Journal of Rheology, Vol.47, No.5 (2003), pp.1227-1247.

(9) Manneville, S., "Recent Experimental Probes of Shear Banding”, Rheologica Acta, Vol.47, No.3 (2008), pp.301-318.

(10) Olmsted, P.D., "Perspectives on Shear Banding in Complex Fluids", Rheologica Acta, Vol.47, No.3 (2008), pp.283-300.

(11) Decruppe, J.P., Cressely, R., Makhloufi, R., Cappelaere, E., "Flow Birefringence Experiments Showing a Shear-Banding Structure in a CTAB Solution”, Colloid \& Polymer Science, Vol.273, No.4 (1995), pp.346-351.

(12) Boukany, P.E., Wang, S.-Q., "Use of Particle-Tracking Velocimetry and Flow Birefringence to Study Nonlinear Flow Behavior of Entangled Wormlike Micellar Solution: From Wall Slip, Bulk Disentanglement to Chain Scission”, Macromolecules, Vol.41, No.4 (2008), pp.1455-1464.

(13) Decruppe, J.P., Lerouge, S., Berret, J.F., "Insight in Shear Banding under Transient Flow”, Physical Review E, Vol.63, No.2 (2001), 022501-1-022501-4

(14) Decruppe, J.P., Greffier, O., Manneville, S., Lerouge, S., "Local Velocity Measurements in Heterogeneous and Time-Dependent Flows of a Micellar Solution”, Physical Review E, Vol.73, No.6 (2006), 061509-1-061509-9

(15) Bécu, L., Manneville, S., Colin, A., "Spatio-Temporal Dynamics of Wormlike Micelles under Shear", Physical Review Letters, Vol.93, No.1 (2004), 018301-1-018301-4.

(16) Hu, Y. Wang, S.Q., Jamieson, A.M., "Rheological and Flow Birefringence Studies of a Shearthickening Complex Fluid - A Surfactant Model System”, Journal of Rheology, Vol.37, No.3 (1993), pp.531-546. 
(17) Fischer, P., Wheeler, E.K., Fuller, G.G., "Shear-Banding Structure Orientated in the Vorticity Direction Observed for Equimolar Micellar Solution", Rheologica Acta, Vol.41, Nos.1-2 (2002), pp.35-44.

(18) Azzouzi, H., Decruppe, J.P., Lerouge, S., Greffier, O., "Temporal Oscillations of the Shear Stress and Scattered Light in a ShearBanding-Shear-Thickening Micellar Solution”, The European Physical Journal E, Vol.17, No.4 (2005), pp.507-514.

(19) Hu, Y.T., Lips, A., "Kinetics and Mechanism of Shear Banding in an Entangled Micellar Solution", Journal of Rheology, Vol.49, No.5 (2005), pp.1001-1027.

(20) Liu, C.-H., Pine, D.J., "Shear-Induced Gelation and Fracture in Micellar Solutions”, Physical Review Letters, Vol.77, No.10 (1996), pp.2121-2124.

(21) Manneville, S., Bécu, L., Grondin, L., Colin, A., "High-Frequency Ultrasonic Imaging: A Spatio-Temporal Approach of Rheology”, Colloids and Surfaces A, Vol.270-271, No. 1 (2005), pp.195-204.

(22) Ouchi, M., Takahashi, T., Shirakashi, M., "Shear-Induced Structure Change and Flow-Instability in Start-Up Couette Flow of Aqueous Wormlike Micelle Solution”, Journal of Rheology, Vol.50, No.3 (2006), 341-352.

(23) Delgado, J., Castillo, R., "Shear-Induced Structures Formed during Thixotropic Loops in Dilute Worm-Micelle", Journal of Colloid and Interface Science, Vol.312, No.2 (2007), pp.481-488.

(24) Yamamoto, T., Hashimoto, T., Yamashita, A., "Flow Analysis for Wormlike Micellar Solutions in an Axisymmetric Capillary Channel”, Rheologica Acta, Vol.47, No.9 (2008), pp.963-976.

(25) Yamashita, A., Yamamoto, T., Hashimoto, T., "Numerical Simulation of Startup Flows of Wormlike Micellar Solutions in an Axisymmetric Capillary Channel using a Modified Bautista-Manero Model”, Nihon Reoroji Gakkaishi, Vol.37, No.2 (2009), pp.69-74.

(26) Chen S., Rothstein, J.P., "Flow of a Wormlike Micelle Solution Past a Falling Sphere", Journal of Non-Newtonian Fluid Mechanics, Vol.116, Nos.2-3 (2004), pp.205-234.

(27) Hashimoto, T., Kido, K., Kaki, S., Yamamoto, T., Mori, N., "Effects of Surfactant and Salt Concentrations on Capillary Flow and Its Entry Flow for Wormlike Micelle Solutions”, Rheologica Acta, Vol.45, No.6 (2006), pp.841-852.

(28) 大内真由美, 高橋勉, 白樫正高, ”二次元急縮小流路において発生する CTAB/NaSal 水溶液の流動誘起構造変化と流動不 安定性”, 日本レオロジー学会誌, Vol.34, No.4 (2006), pp.229-234.

(29) Wheeler, E.K., Fischer, P., Fuller, G.G., “Time-Periodic Flow Induced Structures and Instabilities in a Viscoelastic Surfactant Solution”, Journal of Non-Newtonian Fluid Mechanics, Vol.75, Nos.2-3 (1998), pp.193-208.

(30) 高橋勉, 八子信行, 白樫正高, ” $\mathrm{CPyCl} / \mathrm{NaSal}$ 水溶液の流動誘起構造変化現象と光学的異方性の関係”, 日本レオロジー 学会誌, Vol.29, No.1 (2001), pp.27-32.

(31) Hu, Y.T., Boltenhagen, P., Pine, D.J., "Shear Thickening in Low-Concentration Solutions of Wormlike Micelles. I. Direct Visualization of Transient Behavior and Phase Transitions”, Journal of Rheology, Vol.42, No.5 (1998), pp.1185-1208.

(32) Kadoma, I.A., Egmond, J.W., “Tuliplike Scattering Patterns in Wormlike Micelles under Shear Flow”, Physical Review Letters, Vol.76, No.23 (1996), pp.4432-4435.

(33) Barnes, H.A., Hutton, J.F., Walters, K., An Introduction to Rheology (1989), Chap.2, Elsevier.

(34) Cousset, P., Rheometry of Pastes, Suspensions, and Granular Materials (2005), Chap.1, Wiley.

(35) Fuller, G.G., Mikkelsen, K.J., “Optical Rheometry Using a Rotary Polarization Modulator”, Journal of Rheology, Vol.33, No.5 (1989), pp.761-769.

(36) Fuller, G.G., Optical Rheometry of Complex Fluids (1995), Oxford University Press.

(37) Hashimoto, T., Tsurukawa, T., Mori, N., "Flow Property and Micellar Structures in Capillary Flows of Surfactant Solutions", Nihon Reoroji Gakkaishi, Vol.33, No.1 (2005), pp.1-8.

(38) Kadoma, I.A., van Egmond, J.W., “" "Tuliplike” Scattering Patterns in Wormlike Micelles under Shear Flow”, Physical Review Letters, Vol.76, No.23 (1993), pp.4432-4435.

(39) Yamamoto, T., Sawa, K., Mori, K., "Velocity Measurements for Shear Flows of CTAB/NaSal Aqueous Solutions between Parallel Plates", Journal of Rheology, Vol.53, No.6 (2009), pp.1347-1362. 